\section{Ks. Dariusz Kotecki}

Uniwersytet Mikołaja Kopernika w Toruniu dkotecki@umk.pl

ORCID: 0000-0002-0763-0430

DOI: http://dx.doi.org/10.12775/BPTh.2020.022
Biblica

et

Patristica

Thoruniensia

13 (2020) 4: 487-505

ISSN (print) $1689-5150$

ISSN (online) 2450-7059

\title{
„Czy uważasz, że słusznie jesteś oburzony?" (Jon 4,4) O możliwym powodzie buntu Jonasza wobec miłosierdzia Boga
}

\author{
"Is it right for you to be angry?"(Jon 4:4) \\ On a Possible Reason \\ for Jonah's Rebellion against God's Mercy
}

Streszczenie. Autor artykułu, analizując narrację Księgi Jonasza, dochodzi do wniosku, że głównym jej przesłaniem nie jest - tak jak chce wielu badaczy - ani uniwersalizm zbawczy, ani misyjne powołanie Izraela. Cała narracja koncentruje się na konflikcie między Jonaszem a Bogiem, którego podstawa dotyczy odpowiedzi na pytanie o relację między sprawiedliwością a miłosierdziem Boga. Miłosierdzie Boga okazane Niniwie jest powodem buntu Jonasza. Nie chodzi jednak wcale o Boże przebaczenie, którego adresatami są poganie. Takie miłosierdzie jest akceptowalne dla Jonasza (ocalenie przez Boga pogańskich marynarzy ze sztormu, które prowadzi ich do nawrócenia do jedynego Boga). Niniwa nie jest symbolem świata pogańskiego jako takiego, ale jest symbolem imperializmu, wrogości, prześladowań, agresji wobec ludu Bożego (Iz 10,5-15; Sof 2,13-15; Na). W takim kontekście tym, czego nie potrafi zaakceptować Jonasz, i dlatego się buntuje, jest fakt okazania miłosierdzia przez Boga największemu wrogowi, prześladowcy Izraela, którego symbolem jest Niniwa. Narracja Księgi Jonasza zmierza do ostatniego pytania $(4,10)$, funkcjonującego w narracji jako „permanentna luka", która jako taka nie uzyskuje bezpośredniej odpowiedzi. Do odpowiedzi na nie jest zaproszony Jonasz, są zaproszeni czytelnicy, którzy zamiast narratora powinni dopisać koniec tej historii własnym życiem, Jest to zaproszenie do 1) odkrycia prawdy o Bogu, który ukazuje miłosierdzie wszystkim ludziom, w tym także największym prześladowcom i wrogom oraz do 2) okazania miłosierdzia wrogom i prześladowcom. W ten sposób Księga Jonasza ze swoim przesłaniem przybliża się do ewangelicznego wezwania: „Miłujcie waszych nieprzyjaciół i módlcie się za tych, którzy was prześladują, abyście się stali synami Ojca waszego, który jest w niebie, ponieważ On sprawia, że słońce Jego wschodzi nad złymi i dobrymi, i On zsyła deszcz na sprawiedliwych i niesprawiedliwych" (Mt 5,43-45). 
Abstract. The author of the article analyzing the narrative of the Book of Jonah observes that the central message of the text is neither salvific universalism nor missionary vocation of Israel, as many biblical scholars want to believe. The whole narrative focuses on the conflict between Jonah and God, which concerns the answer to the question about the relation between justice and God's mercy. God's mercy revealed to Nineveh is the reason for Jonah's rebellion. It is not, however, about God's forgiveness towards pagans. Jonah is able to accept such a form of mercy, namely the saving of pagan seamen from the storm by God, which leads to their conversion to the one God. Nineveh is not the symbol of the pagan world as such but the representation of imperialism, hostility, persecution, and aggression towards the people of God (Is 10:5-15; Zep 2:13-15; Na). In this context, what Jonah cannot accept is the fact of God's mercy to the greatest enemy of Israel, symbolized by Nineveh. In the Book of Jonah, the narrative leads to the final question (4:10) functioning in the text as a "narrative gap," which as such remains unanswered. It is not Jonah but the readers who are invited to answer this question through the story of their lives. It is an invitation to 1) discover the truth about God who shows His mercy to all people, even the greatest persecutors and enemies, and 2) to be merciful towards enemies and persecutors. In this way, the Book of Jonah comes closer the Gospel's call: "Love your enemies and pray for those who persecute you, so that you may be sons of your Father who is in heaven; for He causes His sun to rise on the evil and the good, and sends rain on the righteous and the unrighteous" (Mt 5:43-45).

Słowa klucze: Księga Jonasza; miłosierdzie; obraz Boga; miłość do wrogów; luka narracyjna.

Keywords: the Book of Jonah; mercy; the image of God; love of enemies; narrative gap.

Księga Jonasza jest zaliczana w kanonie biblijnym do Dwunastu Proroków Mniejszych, chociaż naprawdę ma niewiele wspólnego z tą częścią Pisma świętego. Na próżno szukać w niej rzeczownika „prorok”; nie ma w niej czasownika „prorokować”, ani „formuły posłańca”; cała treść głoszenia zawarta jest w Jon 3,4: „jeszcze czterdzieści dni, a Niniwa zostanie zburzona”. Jest to księga, która ani razu nie jest cytowana bezpośrednio w NT. Jezus jednak mówi o znaku Jonasza, odnosząc się wyraźnie do treści księgi (Mt 12,38; 16,1-4; Łk 11,29-32)1․

1 Na ten temat zob. A. Malina, Znak Jonasza $w$ tradycji i redakcji synoptycznej (Mt 12,38-42; 16,1-4; Łk 11,29-32), Biblica et Patristica Thoruniensia 2 (2009), s. 100113. Badacze doszukują się relacji między Jon a innymi tekstami ewangelicznymi (por. M.A. Powell, Echoes of Jonah in the New Testament, Word and World 27 (2007), s. 157-164), czy też Dz 10 (por. R.W. Wall, Peter, Son of Jonah: the Conversion of Cornelius in the Context of Canon, JUNT 29 (1987), s. 79-90). 
Wiele trudności przysparza egzegetom określenie jednoznacznego przesłania księgi: czy jest nim relacja między wybraniem jednego narodu a uniwersalizmem zbawczym; czy postępowanie, jakie powinien przyjąć Izrael w stosunku do ludów pogańskich (do obcych); czy jest nim próba usprawiedliwienia Boga, który nie wypełnił gróźb w stosunku do Niniwy; czy może relacja między prorokiem a Bogiem; być może wezwanie do nawrócenia albo działalności misyj$n^{2}{ }^{2}$. Już pobieżna lektura tej księgi pokazuje, że jej głównymi bohaterami jest Jonasz i Bóg, a cała narracja koncentruje się na konflikcie między tymi dwiema postaciami. W ten konflikt zostaje wciągnięty także czytelnik, bowiem Księga ta nie jest tylko „ciekawie opowiedzianą historią, ale przede wszystkim próbą sprowokowania refleksji” czytelnika ${ }^{3}$. Konflikt ten wydaje się nieprzejednany i osiąga swoje apogeum w postawie oburzenia Jonasza w stosunku do Boga. Po tym, kiedy Bóg ulitował się nad Niniwą i nie zesłał na nią kary reakcja Jonasza jest zaskakująca: „Nie podobało się to Jonaszowi i oburzył się” $(4,1)$, potem sam Bóg zadaje dwa razy pytanie Jonaszowi: „Czy uważasz, że słusznie jesteś oburzony” $(4,4)$ i w końcu „Czy słusznie się oburzasz z powodu tego krzewu?" $(4,9)$, na które otrzymuje od proroka odpowiedź: „Słusznie jestem śmiertelnie oburzony" $(4,9)$. Jakie są powody oburzenia Jonasza? Co jest przyczyną konfliktu między prorokiem i Bogiem? Aby odpowiedzieć na to pytanie najpierw prześledzimy krótko tok narracji, aby skupić się, na tym jej fragmencie, który bezpośrednio może nam pomóc odpowiedzieć na postawioną kwestię. Na końcu spróbujemy znaleźć odpowiedź na pytanie o przyczynę Jonaszowego „nie” dla postępowania Boga.

\section{Krótka prezentacja narracji Jon}

Pomijając psalm zawarty w rozdziale drugim (Jon 2,3-10), cała księga składa się $\mathrm{z}$ trzech scen: $2,1-2,2 ; 3 ; 4^{4}$. W pierwszej (Jon 2,1-2,2) Jonasz otrzymuje

2 L. Alonso Schökel, J.L. Sicre Diaz, I Profeti, Roma 1996, s. 1146. Po szczegółowe omówienie różnych interpretacji tej księgi zob. R.E. Clements, The Purpose of the Book of Jonah, SVT 28, Leida 1975, s. 16-28; T.E. Fretheim, The Message of Jonah, Minneapolis 1977; U. Steffen, Die Jona-Geschichte: Ihre Auslegung und Darstellung im Judentum, Christentum und Islam, Neukirchen-Vluyn 1994.

3 P. Briks, Ksiega Jonasza jako element dyskusji nad założeniami reformy państwa izraelskiego w okresie perskim, Scripta Biblica et Orientalia 1 (2009), s. 91.

4 Można całą narrację Jon podzielić także na dwie sekcje, po dwa rozdziały każdy, które otwierają te same słowa klucze wypowiedziane przez Boga: „wstań”, „idź do Niniwy” i „głoś”, po których następuje opis postępowania Jonasza: zob. P. Briks, Opowieść o dziwnym proroku (Ksiegga Jonasza), w: Księgi historyczne Starego Testamentu. Dziejopisarstwo okre- 
zadanie przepowiadania w Niniwie. Prorok jednak nie udaje się do Niniwy, ale wsiada na statek, aby uciec do Tarszisz. Rozpętuje się wielka burza, która cichnie w momencie, kiedy Jonasz zostaje wyrzucony za burtę. Jonasz zostaje uratowany przez wielką rybę, w której wnętrzu znajduje schronienie przez trzy dni i trzy noce i która transportuje go na stały ląd. W drugiej scenie (Jon 3) prorok po raz drugi otrzymuje od Boga to samo zadanie głoszenia upomnienia Niniwie. Tym razem wypełnia je. Niniwa, jej mieszkańcy i król, nawracają się. Ich gesty i wołania są wyrazem wiary w Boga. Bóg jej przebacza. W trzeciej scenie (Jon 4) zostaje zaprezentowany oburzenie Jonasza z powodu miłosiernego postępowania Boga względem Niniwy; następnie oburzenie z powodu uschnięcia krzewu, który dostarczał mu cienia, które staje się punktem wyjścia dla wyjaśnienia prorokowi przez Boga motywu Jego miłosierdzia względem mieszkańców Niniwy.

Analizując narrację Jon, można zauważyć w niej wiele luk, które stanowią strategię narracyjną tej księgi ${ }^{5}$. W. Pikor zauważa: „Luka poprzez brak informacji wnosi do narracji pewien element niejasności i niepewności, który zakłóca ciągłość opowiadanej historii. Takie działanie jest strategią świadomie przyjętą przez narratora, która wykorzystuje lukę dla większego zaangażowania czytelnika w proces interpretacji tekstu" ${ }^{6}$. Nie przeanalizujemy wszystkich luk, ale te, które są kluczowe dla interpretacji tej księgi, ukazując, co tak naprawdę jest sprawą pierwszoplanową.

Pierwszą luką która pojawia się w tekście jest motyw postępowania Jonasza, który nie wypełnia rozkazu Boga: „Wstań, idź do Niniwy, wielkiego miasta i upomnij ją, albowiem nieprawość jej dotarła przed moje oblicze" (Jon 1,2). Jonasz ucieka: „A Jonasz wstał, aby uciec przed Bogiem do Tarszisz. Zszedł do Jafy, znalazł okręt płynący do Tarszisz, uiścił należną opłatę i wsiadł na niego, by udać się nim do Tarszisz, daleko od Pana”. W tekście nie ma żadnej wzmianki, która mogłaby pomóc czytelnikowi w odpowiedzi na pytanie o motywy postepowania Jonasza. Czytelnik musi prześledzić kolejne etapy wydarzeń związanych z Jonaszem, aby poznać odpowiedź na to pytanie. W 4,2 luka zostaje wypełniona kompletnie, ponieważ czytelnik poznaje motyw niewypełnienia rozkazu Boga przez Jonasza. Jonasz po nawróceniu Niniwy jest oburzony na Boga i modli się do Boga, mówiąc:

su judaistycznego, Wprowadzenie w Myśl i Wezwanie Ksiąg Biblijnych 3, cz. II, Warszawa 2007, s. 185-186.

5 Pisał na ten temat W. Pikor, „Luka” jako strategia narracyjna w Księdze Jonasza, Biblica et Patristica Thoruniensia 2 (2009), s. 13-36.

6 W. Pikor, Luka jako strategia, s. 13-14. 
Proszę, Panie, czy nie to właśnie miałem na myśli, będąc jeszcze w moim kraju? Dlatego postanowiłem uciec do Tarszisz, bo wiem, że Ty jesteś Bogiem łagodnym i miłosiernym, nieskorym do gniewu i bogatym w łaskę, litującym się nad niedolą. Teraz Panie zabierz mi proszę, moje życie, albowiem lepsza dla mnie śmierć niż życie $(4,2-3)$.

W tym miejscu pojawia się kolejna luka, wprowadzona pytaniem Boga: „Czy uważasz, że słusznie jesteś oburzony?” (Jon 4,4), na którą czytelnik nie otrzymuje bezpośredniej odpowiedzi. Odpowiedź pojawi się dopiero w 4,9. Nie jest to jednak do końca odpowiedź na pytanie Boga $z$ 4,4, ile raczej na „zmodyfikowane nieco pytanie o oburzenie Jonasza wobec zniszczenia przez Boga krzewu rzucającego cień na jego głowę”7. Odpowiedź Jonasza: „Słusznie jestem śmiertelnie zagniewany" $(4,9)$ prowokuje kolejne pytanie, które można potraktować jako lukę permanentną: „Rzekł Pan: «Tobie żal krzewu, którego nie uprawiałeś i nie wyhodowałeś, który w nocy wyrósł i w nocy zginął. A czyż Ja nie powinienem okazać litości Niniwie, wielkiemu miastu, gdzie znajduje się więcej niż sto dwadzieścia tysięcy ludzi, którzy nie odróżniają swej prawej ręki od lewej, a nadto mnóstwa zwierząt?»" (4,10-11). Chociaż odpowiedź na to pytanie wydaje się oczywista, to jednak sama narracja ją przemilcza. Czytelnik nie wie, jakiej odpowiedzi udzielił Jonasz. Pytanie to jednak angażuje czytelnika także osobiście. Nie jest to pytanie tylko do Jonasza, ale również do czytelnika, które domaga się odpowiedzi osobistej także z jego strony. Można powiedzieć, że zakończenie księgi jest otwartym zakończeniem, które pozostawia wszystko w ręku czytelnika ${ }^{8}$.

Przedstawione luki pokazują, że jako pierwszy zostaje wyeksponowany w fabule konflikt między Jonaszem a Bogiem. W zasadzie cała historia Jonasza mogłaby się skończyć w 3,10 (po drugiej scenie). Tutaj bowiem wydaje się być rozwiązana konfrontacja Jonasza z Bogiem. Prorok przecież udaje się do Niniwy. Jego słowo wywołuje nawrócenie i tym samym oszczędzenie jej przez Boga. Mielibyśmy w tym miejscu „komfortową konkluzję" 9 . Pojawia się jednak kolejna komplikacja $(4,1)$, która odkrywa przed czytelnikiem całą prawdę o Jonaszu. Konflikt między Jonaszem i Bogiem w rzeczywistości trwa dalej. Tym razem zostaje ukazany jednak prawdziwy fundament tego konfliktu, który rzuca światło na dotychczasowe postępowanie proroka.

7 Zob. ibidem, s. 18-19.

8 Por. W.B. Crouch, To Question an End, to End a Question: Opening the Clousure of the Book of Jonah, JSOT 62 (1994), s. 101-112; W. Pikor, Luka jako strategia, s. 35-36.

9 Zob. W.B. Crouch, To Question, s. 105. 


\section{Powody ucieczki Jonasza}

Opisując reakcję Jonasza na miłosierne postępowanie Boga lub też na fakt nawrócenia się mieszkańców Niniwy i uniknięcia przez nich zasłużonej kary ${ }^{10}$, narrator skupia się najpierw na jego reakcji wewnętrznej: „Nie podobało się to Jonaszowi i oburzył się" $(4,1)$. Następnie zostają przedstawione motywy tego oburzenia, które zarazem zdradzają powód ucieczki Jonasza do Tarszisz:

Proszę, Panie, czy nie to właśnie miałem na myśli, będąc jeszcze w moim kraju? Dlatego postanowiłem uciec do Tarszisz, bo wiem, że Ty jesteś Bogiem łagodnym (hbr. 'El hannûn) i miłosiernym (hbr. rachûm), nieskorym do gniewu ('erek 'aphajim) i bogatym w łaskę (hbr. rab chesed). i litującym się nad niedolą ( $w^{e}$ niham al-haraah). Teraz, Panie, zabierz mi proszę, moje życie, albowiem lepsza dla mnie śmierć niż życie $(4,2-3)$.

W 1,2-3 ucieczka Jonasza do Tarszisz była zupełnie niezrozumiała. Teraz uzyskuje ona pełne wyjaśnienie. Co jest tak naprawdę powodem ucieczki Jonasza? Na pewno ucieczka Jonasza była wymierzona przeciwko Bogu, ale czy: „Dezercja Jonasza «sprzed oblicza Boga» $(1,2.3)$ była ucieczką przed słowem, którego proklamacja mogła doprowadzić do nawrócenia mieszkańców Niniwy, ale tym samym stać się powodem do oskarżenia Jonasza o bycie fałszywym prorokiem wobec niezrealizowania się proklamowanego przez niego słowa"? ${ }^{11}$.

Jonasz w rozmowie z Bogiem przytacza tradycyjne wyznanie wiary, którego pierwowzór znajduje się w jednym $\mathrm{z}$ najstarszych tekstów Biblii Hebrajskiej, mówiących o przymiotach Boga. Jest to tekst z Wj 34,6-712, w którym czytamy: „Przeszedł JHWH przed jego (Mojżesza) obliczem i wołał: JHWH, JHWH, Bóg miłosierny i litościwy, cierpliwy, bogaty w laskę i wierność, zachowujący łaskę w tysiączne pokolenie, przebaczający niegodziwość, niewierność, grzech, lecz nie pozostawiający go bez ukarania, ale zsyłający kary za niegodziwość ojców na synów i wnuków aż do trzeciego, i czwartego pokolenia”. Tekst ten został umieszczony w kontekście grzechu Izraela ze złotym cielcem i prośby Mojżesza o miłosierdzie dla krnąbrnego narodu i funkcjonuje jako odpowiedź Boga na prośbę Mojżesza: „Spraw, abym ujrzał Twoją chwałę” $(33,18)$. Ta odpowiedź zostaje przygotowana w narracji przez szereg elementów. Najpierw

10 W. Pikor, „Luka” jako strategia, s. 25.

11 Tak: ibidem, s. 22.

12 Na temat Wj 36,6-7 zob. D. Kotecki, „On Bogiem wiernym, a nie zwodniczym” (Pwt 32,4). Refleksja biblijno-teologiczna nad wiernością Boga w Starym Testamencie, CT LXXV (2005) n. 2, s. 18-23. W tym miejscu artykułu korzystam z tego artykułu. 
Bóg mówi: „Ja sprawię, że przejdzie cała moja dobroć przed twoim obliczem i ogłoszę (wyjaśnię?) imię JHWH przed twoim obliczem, gdyż ja wyświadczam łaskę, komu chcę i miłosierdzie, komu mi się podoba" $(32,19)$. Mojżesz nie będzie mógł zobaczyć oblicza Boga. Z tą prośbą łączy się ta część narracji, która rozpoczyna się w 34,5: „I zstąpił JHWH w obłoku i zatrzymał się z nim tam i wypowiedział imię JHWH"13.

Tekst z Wj 34,6-7 - z wielkim prawdopodobieństwem - można potraktować jako wyznanie wiary starożytnego Izraela. Cała proklamacja wychodzi z ust Boga, który jednak nie mówi o sobie w pierwszej osobie, ale w trzeciej. W ten sposób wydaje się, że tekst nie ma charakteru autoprezentacji Boga, ale właśnie wyznania wiary ze strony Izraela. Nie przez przypadek jednak zostaje on włożony w usta Boga. Autorowi chodziło chyba o podkreślenie zgodności wyznawanej wiary z tym, co sam Bóg ma do powiedzenia o sobie. Następuje tutaj prawdziwe spotkanie Teologii jako „mowy Boga” z teologią jako „mowy o Bogu”. Nie jest to jednak, jak dobrze zauważył Mello, typowe wyznanie wiary, które spotykamy w Starym Testamencie, a które mają zawsze jako punkt odniesienia wydarzenie historyczne, jak np. tzw. credo historyczne Izraela (por. Wj 20,2; Pwt 6,21; 26,5). Brak odniesień historycznych może świadczyć o starożytności tej formuły. To wyznanie z jednej strony koncentruje się na imieniu Boga i na Jego atrybutach, $z$ drugiej zaś nie ma formy opowiadania, ale jest prawdziwym opisem teologicznym i to być może najważniejszym w całym Starym Testamencie ${ }^{14}$.

Porównując ten tekst $\mathrm{z}$ Jon 4,2-3, należy powiedzieć, że należy on do grupy tekstów z BH, które podejmują objawienie natury Boga z Wj 34,6-7 (Lb 14,18; Pwt 7,9; Ne 9,17; 2Krn 30,9; Ps 86,15; 103,8; 145,8; Na 1,3; J1 2,13 i Jon $4,2)$, co jest świadectwem jej ważności dla sposobu pojmowania rzeczywistości Boga ${ }^{15}$. Z całej gamy terminów z Wj 34,6-7 w słowach Jonasza spotykamy te, które koncentrują się na miłosierdziu Boga (nie zachowują zestawienia miłosierdzia i sprawiedliwości), podobnie jak to mamy w tekstach pochodzących prawdopodobnie z okresu po niewoli babilońskiej (por. Ne 9,17; $2 \mathrm{Krn} 30,9$; Ps 86,$15 ; 103,8 ; 145,8 ; \mathrm{Jl} 2,13)$. Takie samo wyznanie znajduje się w Jl 2,13. Tylko w tych dwóch tekstach w całej Biblii używa się określenia Boga jako „litującego się nad niedolą”. Jonasz wie, że Bóg jest „Bogiem łagodnym (hbr. 'El hannûn) i miłosiernym (hbr. rachûm), nieskorym do gniewu ('erek

13 Nie wiadomo, kto jest podmiotem czasownika „zatrzymać się” i „powiedzieć” - jeszcze JHWH, czy już Mojżesz.

14 Por. A. Mello, Il Dio miserciordioso e gli attributi della sua misericordia (Es 34,6-7), PSV 29 (1994), s. 38.

15 Por. B.S. Childs, Il libro dell'Esodo, s. 614. 
'aphajim) i bogatym w łaskę (hbr. rab chesed) i litującym się nad niedolą ( $w^{e-}$ niham 'al-haraah)". W wypowiedzi Jonasza zostaje dodane ostatnie wyrażenie, które bezpośrednio odnosi się do sposobu postepowania Boga opisanego w 3,10: „i ulitował się Bóg nad niedolą (hbr. wejinachem 'elohim 'al-haraah), którą postanowił na nich sprowadzić". Podobne sformułowania spotkać można w Wj 32,14 i Jr 26,13.19. Bóg zmienia swoje postanowienie („nawraca się"), kiedy człowiek się nawraca. W tym miejscu mogłaby skończyć się historia Jonasza. Jonasz jednak nie akceptuje takiego stanu rzeczy. Jonasz wie, że Bóg jest miłosierny i dlatego ucieka. Nie akceptuje działania Boga -wydaje się, że to z dwóch powodów ściśle ze sobą powiązanych - ponieważ stworzył swój własny obraz Boga oraz ponieważ, co w konsekwencji prowadzi do braku w okazaniu miłosierdzia Niniwitom ze strony proroka. Grzeszna Niniwa w oczach Jonasza zasługuje tylko i wyłącznie na zagładę. On ma żal do Boga. W jego myśleniu sprawiedliwość powinna panować nad miłosierdziem i dlatego też $\mathrm{z}$ tradycyjnego wyznania wiary w miłosierdzie Boga czyni Bogu zarzut o złamanie zasad sprawiedliwości ${ }^{16}$. Jak zauważa T. Tułodziecki: „W jego postawie daje się zauważyć wielki kontrast: To, co było dla Mojżesza i Izraelitów fundamentem nadziei jest dla proroka podstawą gniewu i zwątpienia. Jonasz obstaje przy swojej prawdzie: grzech i nieprawość muszą być surowo ukarane"17. Opis wewnętrznej postawy Jonasza wobec mieszkańców Niniwy i samego Boga można wyprowadzić także ze statystyki narracyjnej. Jak zauważa U. Struppe, Jonasz miastu Niniwie poświęca zaledwie 5 słów, marynarzom 16 słów a swoim żalom do Boga aż 38 słów ${ }^{18}$. Dla Jonasza „Z Bogiem sprawiedliwym można zrobić rachunki i przewidzieć rezultaty [...]; na Boga miłosiernego nie można liczyć, ponieważ jest zdolny do przebaczenia nawet największym przeciwnikom”19. Jonasz swoją postawą zdaje się mówić do Boga: „Boże, Ty przesadzasz”. Z całej narracji Księgi wynika, że dla Jonasza Bóg jest stworzycielem świata $(1,9)$, jest potężnym wybawcą dla tego, kto wzywa pomocy $(2,2-9)$. Nazywając Boga jako „Boga nieba, który stworzył niebo i ziemię” Jonasz identyfikuje Go jako najwyższe bóstwo, posiadające absolutną władze nad światem stworzonym. Jest On zatem Bogiem wszechmogącym i dlatego musi być egzekutorem sprawiedliwości ${ }^{20}$. Przed takim Bogiem nie ma ucieczki i być może dlatego sam Jonasz prosi marynarzy, aby wyrzucili go do morza, co tym samym skutko-

16 Por. W. Pikor, Luka jako strategia, s. 22.

17 T. Tułodziecki, Jonasz wobec pogan, Biblica et Patristica Thoruniensia 2 (2009), s. 46.

18 U. Struppe, Die Bücher Obadja, Jona (NSK 24/1), Stuttgart 1996, s. 128.

19 L. Alonso Schökel, J.L. Sicre Diaz, I Profeti, s. 1172.

20 Na temat obrazu Boga w Jon zob. T.E. Fretheim, The Exaggerated God of Jonah, Word and World 27 (2007) n. 2, s. 125-134. 
wałoby jego śmiercią i uniknięciem posłania go do Niniwitów. Miłosierdzie wydaje się dla Jonasza zaprzeczeniem sprawiedliwości. On jest raczej zwolennikiem sprawiedliwości opartej na zasadzie wzajemności (retrybucja), według której w stosunku do winy i grzechu nie ma miejsca na miłosierdzie. Być może jednak Jonasz, zgadzając się z podstawowym wyznaniem wiary Izraela $(4,2)$, jest zwolennikiem ograniczenia zasięgu jego zastosowania: Boże miłosierdzie i przebaczenie winny być zarezerwowane tylko dla Izraelitów ${ }^{21}$. Sam tekst zaprasza do wielu interpretacji. W jednym (idea retrybucji), jak i drugim przypadku (ograniczenie miłosierdzia) Jonasz posiada swoje spojrzenie na Boga, swój obraz Boga i w ten obraz chciałby wtłoczyć prawdziwego Boga. Bóg zaś nie może być kontrolowany i manipulowany ${ }^{22}$.

Nie jest wykluczone, że już w uprzedniej narracji znajdują się przesłanki, które wskazują na taki sposób myślenia Jonasza. Już w samej postawie Jonasza w czasie sztormu, kiedy ten prosząc marynarzy o wrzucenie do morza, sam sobie chce wymierzyć karę, przysługującą prorokowi, który odmawia spełnienia Bożej woli (por. $1 \mathrm{Krl} 13,22.24 ; 20,36$ ), pokazuje się jako ten, który w stosunku do samego siebie odrzuca miłosierdzie Boga. W drugim posłaniu Jonasza Bóg mówi mu: „Wstań, idź do Niniwy, wielkiego miasta, i głoś jej upomnienie, które Ja ci zlecam". Nie zostaje tutaj de facto sprecyzowany przedmiot upomnienia. Mówi się jedynie o upomnieniu, używając neutralnego rzeczownika qerîāh z doprecyzowaniem, że będzie to słowo: „które mówi do niego” Bóg. Mamy zatem kolejną lukę, której nie wypełnia jednak spełnienie przez Jonasza rozkazu Boga. W 3,4 Jonasz kieruje do mieszkańców Niniwy stwierdzenie: „Jeszcze czterdzieści dni i Niniwa zostanie obrócona”. Cała tradycja biblijna zakłada, że upomnienie jest głoszone po to, aby ktoś się nawrócił. Tutaj nie spotyka się wezwania do nawrócenia. W. Pikor zauważa:

Dowodzi ona [wyrocznia z 3,4], że Jonasz poddał pewnej manipulacji słowo, które otrzymał od Jahwe. Ustalenie zakresu wprowadzonych przez niego zmian pozostaje hipotetyczne. Pytań, na które nie ma jednoznacznej odpowiedzi, jest wiele: - dlaczego Jonasz pominął tradycyjne formuły wprowadzające wyrocznię prorocką, które podkreślały, że podmiotem mówiącym jest Bóg? - dlaczego prorok użył czasownika hāpāk komunikującego dwuznaczność, co do losu Niniwy? Jej „obrócenie” może oznaczać albo jej zniszczenie (w takim znaczeniu czasownik ten opisuje zagładę Sodomy i Gomory w Rdz 19,21.25.29; Pwt 29,33; Iz 13,19; Jr 20,16; Am 4,11), albo jej nawrócenie i wybawienie (taki sens przyjmuje ten czasownik

21 Por. T.E. Fretheim, The Exaggerated God, s. 132.

22 Mamy tutaj do czynienia z czymś podobnym do grzechu uczynienia złotego cielca przez Izraelitów (Wj 23), który był niczym innym, jak zmaterializowaniem Boga, aby w ten sposób go sobie podporządkować i nim manipulować. 
w Pwt 23,5; Jr 31,13; Ps 66,6 - wybawienie, w 1 Sm 10,6 - nawrócenie); - okres czterdziestu dni sugeruje nieodwracalność tej zapowiedzi, czy też stwarza nadzieję na jej zmianę? Jeszcze jedno spojrzenie retrospektywne na słowo, które Jonasz miał głosić Niniwie, jest zauważalne w 3,10. Już po nawróceniu jej mieszkańców Bóg zmienia swoja decyzję odnośnie do „nieszczęścia (hārā'āh), które powiedział, że im uczyni”. To sugerowałoby, że Jonasz miał rzeczywiście zapowiadać karę dla Niniwitów. Czy jednak tylko do tego miało ograniczać się jego słowo? Zwykle bowiem w wyroczniach kary pojawiały się jeszcze inne elementy (np. oskarżenie wymieniające grzechy), sama zaś zapowiedź, mimo że brzmiała bezwarunkowo, miała skłonić adresatów do zamiany postępowania ${ }^{23}$.

Jonasz staje w pewnej konfrontacji ze słowem Boga.

Być może zatem Jonaszowi wcale nie zależało na nawróceniu Niniwy, ponieważ w jego myśleniu postępowanie Niniwitów, wyrażone w tekście, najpierw w 1,2 przy użyciu rzeczownika rāāh („niegodziwość”), a potem doprecyzowane w 3,8 jako derek hārāāh („,złe postępowanie”) i chāmās („gwałt”), zasługuje jedynie na karę, tak jak pokolenie przedpotopowe $\mathrm{z}$ powodu powszechnie dokonywanego gwałtu (chāmās) zasługiwało na karę potopu (Rdz 6,11: „Ziemia popsuła się w oczach Boga i ziemia napełniła się gwałtem”). „Ale właśnie na przykładzie tego skumulowanego zła Księga Jonasza ukazuje moc Bożego Miłosierdzia, dla którego nie ma barier, granic i krat. Mieszkańcy Niniwy i ich gotowość do nawrócenia tworzą wymowny kontrast $\mathrm{z}$ egoistyczną postawą proroka Jonasza" 24 .

Jonasz na koniec swojej modlitwy - już po nawróceniu Niniwy - prosi Boga o śmierć: „Teraz, Panie, zabierz, proszę duszę moją ode mnie, albowiem lepsza jest dla nie śmierć niż życie" $(4,3)$. Słowa te przypominają prośbę Eliasza, który ucieka przed Jezabel w $1 \mathrm{Krl}$ 19,4. W przypadku Jonasza nie do końca są znane motywy tej prośby. Być może prosi Boga o śmierć, ponieważ postępowanie

23 W. Pikor, „Luka” jako strategia, s. 25. Normalny schemat wyroczni skazującej jakąś społeczność jest następujący: formuła posłańca („Tak mówi Pan”), oskarżenie ogólne i oskarżenie szczegółowe, obwieszczenie kary. W Biblii można jednak spotkać pewne modyfikacje tego schematu, polegające na: 1) odwróceniu kolejności jego elementów (np. Am 9,8-10); 2) wyeliminowaniu jakiegoś elementu: zaprezentowanie tylko oskarżenia (np. Am 5,1-2; 6,7-10; Jr 2,10-25) lub tylko obwieszczenie kary (np. Oz 8,16-18; Jr 13,12-14; Iz 7,18-20.21-22); 3) rozszerzenie pierwotnego schematu przez rozbudowanie oskarżenia (np. Oz 10,1-2; Am 2,9-11; Iz 5,4) lub kary (np. Iz 5,26-30; Jr 4,5-29; 6,1-8). W Jon to, co głosi prorok w 3,4, jest niezgodne z poleceniem, jakie otrzymuje za pierwszym razem: „Wstań, idź do Niniwy - wielkiego miasta - i upomnij ją, albowiem nieprawość jej dotarła przed moje oblicze" $(1,2)$, zob. J.L. Sicre, Profetismo in Israele, . Il Profeta - I Profeti Il messaggio, Roma 1995, s. 165-166.

24 T. Tułodziecki, Jonasz wobec pogan, s. 42. 
Boga, postawiło go w złym świetle, jako proroka, którego słowa się nie spełniły („fałszywy prorok”). Być może jednak jego prośba o śmierć jest jego sprzeciwem wobec prawdziwego obrazu Boga. On chce bronić swojego obrazu Boga nawet za cenę życia, ponieważ uważa, że Bóg nim manipulował, aż do zaparcia się samego siebie ${ }^{25}$. W tym miejscu pojawia się pytanie Boga: „Czy uważasz, że słusznie jesteś oburzony?” $(4,4)$, które funkcjonuje - jak już zostało zauważone - jako „luka” narracyjna, która otrzymuje swoje wypełnienie w 4,9. Zanim jednak ta luka zostanie wypełniona Jonasz wychodzi z miasta: „Jonasz wyszedł z miasta, zatrzymał się po jego stronie wschodniej, tam uczynił sobie szałas i usiadł w cieniu, aby widzieć, co się będzie działo w mieście" $(4,5)$. Z punktu widzenia chronologii opowiadania, wiersz ten mógł się znaleźć natychmiast po przepowiadaniu Jonasza $(3,4)$. Narrator jednak lokuje go w tym miejscu, kiedy Jonasz już wie, że Niniwa się nawróciła i zna również reakcje Boga. W narracji nie zostają wyjaśnione przyczyny wykonanych przez Jonasza czynności: wyjście z miasta, zbudowanie szałasu i siedzenie w cieniu. Być może są one symbolicznym opisem stanu wewnętrznego Jonasza, który niejako „okopuje się” na swojej pozycji w relacji do Boga. Jego oczekiwanie na to, „co będzie działo się w mieście” być może jest oczekiwaniem na nawrócenie Boga, aby Ten odstąpił od swego zamiaru nie zniszczenia Niniwy. To jest jedynie jedna z możliwych interpretacji.

W tym miejscu rozpoczyna się opis działania Boga. Bóg sprawia, że nad Jonaszem wyrasta krzew, który dostarcza mu cienia. Następnie Bóg zsyła robaczka, który doprowadza do uschnięcia krzewu $(4,7)$ i wczesnym rankiem zsyła gorący, wschodni wiatr. Słonce praży Jonasza do tego stopnia, że życzy sobie śmierci $(4,8)$. Cała sytuacja wydaje się zupełnie normalna. Otrzymuje jednak ona komentarz $\mathrm{w}$ pytaniu Boga, w którym rozbrzmiewa uprzednie pytanie o oburzenie Jonasza z 4,4. Z pytania: „Czy słusznie się oburzasz z powodu tego krzewu” $(4,9)$, czytelnik dowiaduje się o wewnętrznym stanie Jonasza. On jest oburzony z powodu uschnięcia krzewu. Czytelnik ma jednak świadomość, że adresatem tego oburzenia jest sam Bóg, który zesłał robaczka, aby uszkodził krzew $(4,7)$. Można w tym miejscu zadać pytanie o sens całego działania Boga. Pytanie Boga (rozpoczyna się w tłumaczeniu dosłownym od: „Czy dobrze czynisz?) oskarża go o złe postępowanie, z którego musi być Jonasz uwolniony. "Jego idee teoretyczne o Bogu, które go pokierowały do działania dwuznacznego (ucieczka), muszą zostać skorygowane przez doświadczenie osobiste"26. Odpowiedź Jonasz na pytanie Boga jest jednoznaczna: „Słusznie gniewam się śmiertelnie" (4,9b). 
Teraz w narracji pojawia się chyba najważniejsza "luka” dla interpretacji księgi, w formie bardzo długiego pytania retorycznego, którego forma przekracza kanony prozy hebrajskiej ${ }^{27}$ : „Rzekł Pan: «Tobie żal krzewu, którego nie uprawiałeś i nie wyhodowałeś, który w nocy wyrósł i w nocy zginął. A czyż Ja nie powinienem okazać litości Niniwie, wielkiemu miastu, gdzie znajduje się więcej niż sto dwadzieścia tysięcy ludzi, którzy nie odróżniają swej prawej ręki od lewej, a nadto mnóstwa zwierząt?»" (4,10-11). W. Pikor zauważa:

Słowo, którym Bóg zwraca się do Jonasza, buduje kontrast między prorokiem przejmującym się losem krzewu $(4,10)$ a Bogiem litującym się nad Niniwą $(4,11)$. Opozycja między tymi podmiotami formalnie jest podkreślona użyciem tego samego czasownika hûs dla wyrażenia ich postawy. Zdanie to nie ma charakteru stwierdzenia. pomimo braku pytajnika hă syntaktycznie przyjmuje ono funkcję pytania retorycznego. Wynika ona z kombinacji formy qatal czasownika hûs z następującą dalej formą yiqtol tego samego czasownika, która łączy spójnik waw (z negacją $l l^{\prime}$ ), wprowadzając ideę opozycji między zachowaniem Boga i Jonasza ${ }^{28}$.

Bóg poprzez to pytanie ukazany jest jako ten, który próbuje przekonać Jonasza do zrozumienia swojego postępowania względem Niniwy. Czyni to oświecając sens uprzednich wydarzeń (uschnięcie krzewu) z życia Jonasza. Problem Jonasza jest natury teologicznej. Chodzi o prawdziwy obraz Boga. Zatem pytanie Boga jest wezwaniem do nawrócenia teologalnego. To pytanie świadczy o wyjątkowości narracji księgi Jonasza. Na koniec narracji zostaje wprowadzona luka, która nie kończy konfliktu między Jonaszem a Bogiem, ale pozostaje otwarta. Czytelnik nie tylko, że nie zna odpowiedzi, jakiej udzielił Jonasz na postawione pytanie, ale także sam czytelnik musi się opowiedzieć po którejś ze stron konfliktu. Kto ma rację: Jonasz czy Bóg? Czytelnik zostaje zaproszony, aby dopisać koniec tej historii swoim życiem. Słusznie zauważa W. Pikor: „W perspektywie całej Biblii hebrajskiej wyjątkowość Księgi Jonasza polega na umieszczeniu na jej końcu luki, której domknięcie zależy już wyłącznie od czytelnika"29. W Księdze Jonasza Niniwa się nawraca, Bóg się nawraca, a czy nawróci się Jonasz w swoim spojrzeniu na Boga i na grzesznika, czy nawróci się czytelnik ze swoim obrazem Boga? Cała księga przez to otwarte zakończenie staje się zaproszeniem do nawrócenia teologalnego skierowanym nie tylko do Jonasza, ale każdorazowego czytelnika tej księgi. „Jest to pytanie, które Bóg kieruje do Jonasza i w Jonaszu do czytelników; pytanie zarówno do tych,

27 Ibidem.

28 W. Pikor, „Luka” jako strategia, s. 21.

29 Ibidem, s. 36. 
którzy uważają się za dobrych i pogardzają złymi, jak i do tych, którzy widzą siebie złymi i są w poszukiwaniu nadziei [...]"30. Czy powyższe stwierdzenia można określić jako definitywne przesłanie tej księgi? To, co może zainteresować czytelnika to próba odpowiedzi na pytanie, dlaczego Jonasz tak uparcie odrzuca Boży punkt widzenia.

\section{Przyczyna Jonaszowego „nie" dla miłosierdzia Boga względem Niniwy}

Postawa Jonasza prowokuje jeszcze jedno pytanie: dlaczego Jonaszowi było tak trudno zaakceptować miłosierdzie Boga względem Niniwy i tym samym dlaczego jest tak bardzo przekonany o słuszności swojego spojrzenia na Boga i swoje postępowanie?

Większość egzegetów próbuje znaleźć odpowiedź na pytanie poprzez próbę powiązania przesłania tej księgi z kwestią datacji jej powstania. Jako prezentację tych poglądów przytoczymy dwie wypowiedzi. P. Briks zauważa, że Jon jest

swoistym głosem w dyskusji o kierunku zmian, jakie zachodziły w Izraelu w V lub na oczątku IV w. przed Chr. [...]. Napisał [autor] księgę [...], w której pod pozorem opowiadana o znanej postaci historycznej, przedstawia słabe strony i absurdy albo jeszcze przeprowadzonych reform, albo już ich skutków. [...]. Faktem pozostaje, że judaizm w formie zapoczątkowanej reformami Ezdrasza i Nehemiasza stał się dominującym nurtem duchowości izraelskiej i ostatecznie doprowadził do alergicznej niechęci do obcych oraz momentami komicznego legalizmu ${ }^{31}$.

Tomasz Tułodziecki podkreśla:

Istotną rolę w ustaleniu datacji Księgi Jonasza odgrywa jej podstawowe przesłanie teologiczne. [...] Zbieżność tematów teologicznych widać również pomiędzy Jonaszem a księgami Ezdrasza i Nehemiasza. Chodzi tu o pozytywne spojrzenie na zachowanie pogan u proroka (marynarze na okręcie, mieszkańcy Niniwy), które polemizuje $\mathrm{z}$ wybitnie separatystyczną wizją świata ukazaną $\mathrm{w}$ powygnaniowych dziełach wielkich reformatorów Izraela: Edrasza i Nehemiasza. Opowiadanie o Jonasz, podobnie jak Księga Rut byłaby świadectwem o dyskusji, jaka toczyła się na

31 P. Briks, Księga Jonasza jako element dyskusji, s. 104-105. 
przełomie V i IV wieku przed Chrystusem nad rolą ludzi obcego pochodzenia [pogan] w odrodzonej po niewoli społeczności żydowskiej ${ }^{32}$.

Nie wszyscy badacze zgadzają się z tak późnym datowaniem tej księgi. T. Brzegowy, chociaż sam zauważa, 1) że

Księga zaczęła powstawać już w VIII w. wokół osoby Jonasza [chodzi o Jonasza z Gat Chefer, syna Amittaja, działającego na początku VIII w. przed Chr.: 2 Krl $14,25]$; proces ten był kontynuowany w gronie jego uczniów. Jak długo trwał okres ustnego przekazu i kiedy księgę zredagowano na piśmie, trudno powiedzieć. Ale moment przejścia od tradycji ustnej do formy spisanej nie ma istotnego znaczenia, gdyż treść przekazu była uformowana. Skoro zaś nazwa „Niniwa” ma w księdze Jonasza dosłowne, historyczne znaczenie, to tradycja o wyprawie Jonasza do Niniwy powinna się uformować przed 612 r., tzn. przed zburzeniem Niniwy ${ }^{33}$

i 2) nie przekonują go argumenty zwolenników późnego datowania księgi zaczerpnięte z krytyki rodzajów literackich, teologii, kilku arameizmów i form językowych ${ }^{34}$, to jednak w religijnym przesłaniu tej księgi widzi przede wszystkim wezwanie do misji Izraela wobec pogan oraz przekazanie Bożego pragnienia zbawienia pogan. Nie jest zatem wcale tak ważne, czy przyjmiemy wcześniejsze czy późniejsze datowanie tej księgi. W narracji księgi - według cytowanych autorów - prorok Jonasz zostałby przedstawiony w księdze jako ten, który odrzuca miłosierdzie Boga względem pogan, których symbolem czy prototypem stałaby się Niniwa i to byłaby główną przyczyną buntu Jonasza. Czy stosunek Jonasza do pogan, odrzucenie przez niego idei uniwersalizmu, mogło być przyczyną tak zdecydowanego „nie” dla miłosierdziu Boga względem Niniwy? Ma rację T. Brzegowy, że „teologiczna idea uniwersalizm zbawczego jest tak stara, jak religia Izraela" 35 . Jaka byłaby zatem nowość przesłania tej księgi? Czy tylko ta, że beneficjantami Bożego miłosierdzia nie jest tylko Lud Przymierza, ale także ludy pogańskie? W samej narracji Jonasz po raz pierwszy spotyka pogan

32 T. Tułodziecki, Jonasz jako świadek diaspory asyryjskiej, Biblica et Patristica Thoruniensia 11 (2018) 2, s. 206. Zob. także, idem, Jonasz wobec pogan, s. 37-48; E. Zawiszewski, Ksieggi prorockie, Pelplin 1998, s. 223; T. Brzegowy, Prorocy Izraela, cz. II, Academica 19, Tarnów 2003, s. s. 85-93.

33 T. Brzegowy, Miłosierdzie Boże nie zna granic (Księga Jonasza), w: Wielki świat starotestamentalnych proroków. Od początków profetyzmu do Niewoli Babilońskiej, Wprowadzenie w Myśl i Wezwanie Ksiąg Biblijnych 4, Warszawa 2001, s. 139.

34 Te argumenty czytelnik może odnaleźć w: P. Briks, Księga Jonasza jako element dyskusji, 92-98; T. Tułodziecki, Jonasz jako świadek, s. 197-207.

35 T. Brzegowy, Miłosierdzie Boże nie zna granic, s. 140, cała argumentacja zob. s. 144-148 . 
w osobach marynarzy (Jon 1,4-16). Sami żeglarze byli jedną z grup zawodowych najbardziej pogardzanych przez Izraelitów i to z dwóch powodów: 1) pływali po morzu, które przez Żydów było postrzeganie jako miejsce zamieszkiwania tajemniczych potworów i było symbolem sił zła czy tego wszystkiego, co przeciwstawne Bogu; 2) pływając po różnych akwenach stykali się nieustannie z ludami pogańskim i sami często oddawali cześć bóstwom pogańskim ${ }^{36}$. Załoga statku, na który wsiada Jonasz była prawdopodobnie międzynarodowa, złożona $\mathrm{z}$ różnych nacji pogańskich, które czciły swoje bóstwa, o czym świadczy $\mathrm{w}$ narracji ten moment, kiedy w chwili rozpętania się burzy wszyscy- oprócz Jonasza - modlą się do swoich bóstw (Jon 1,5). Jonasz zdaje sobie sprawę, że w wyniku wyrzucenia go za burtę wody przestaną się burzyć a tym samym jego pogańscy towarzysze dostąpią wybawienia. Jonasz zatem od samego początku nie odrzuca miłosierdzia Boga względem pogan, odrzuca je jednak względem Niniwy? Celem ucieczki Jonasza staje się Tarszisz, miasto, które w narracji zdaje się wskazywać na ekstremalny zachód, na miejsce, które funkcjonuje jako przeciwwaga dla wschodniej Niniwy. Tarszisz reprezentuje także świat pogański. W postępowaniu Jonasza byłoby zatem coś nielogicznego: nie chce pozytywnie odpowiedzieć na wezwanie Boga i iść do pogańskiej Niniwy, ale ucieka do innego pogańskiego miasta. Czym pogańska społeczność Niniwy różniła się od całego świata pogańskiego?

Wybór Niniwy jako adresata przesłania prorockiego jest kluczem dla zrozumienia całego przesłania tej księgi ${ }^{37}$. Nie ulega wątpliwości, że Niniwa - stolica imperium asyryjskiego była widziana jako społeczność pogańska, nie jest jednak w Biblii symbolem świata pogańskiego jako takiego. W świadomości Izraela, Niniwa - począwszy od czasów Sennaheryba (704-681), następcy słynnego Sargona II aż do jej upadku w 612 r. - bardziej niż miasto pogańskie pozostaje symbolem imperializmu, agresywnej przemocy, opresji i niegodziwości względem ludu Bożego (por. Iz 10,5- 15; Sof 2,13-15; Na) ${ }^{38}$. Staje się niejako prototypem wroga Izraela, któremu należy się tylko zagłada. Wśród wszystkich wymienionych tekstów prorockich najmocniej wybrzmiewa Nahum. Cała Księga Nahuma zgodnie z jej tytułem jest poświęcona zagładzie znienawidzonej Niniwy, która jest przyrównywana do lwa rozszarpującego swe ofiar $(2,13)$, do miasta krwawego, będącego pełne kłamstwa i grabieży $(3,1)$, które z powodu swojego okrucieństwa nie zasługuje na żądną litość $(3,19)$. Takie spojrzenie ma swoje uzasadnienie historyczne $\mathrm{w}$ relacjach Izraela ale także Judy

36 P. Briks, Księga Jonasza jako element dyskusji, s. 103.

37 Tak: J.L. Sicre, Profetismo in Israele. Il Profeta - I Profeti - Il messaggio, Roma 1995, s. 380 .

38 Na temat tych tekstów zob. tamże, s. 496-502. 
z Asyrią. Królestwo Samarii złożyło po raz pierwszy daninę Asyrii w 841 r., co oznaczało poddanie się króla Jehu pod dominację Salmanassara III. Adad Nirari III odebrał haracz od króla Samarii Joasza w 802 r. W 738 r. król Izraela Menachem zapłacił trybut Tiglat-Pileserowi III. Podobnie uczynił król Ozeasz w 732 r. W 701 r. Sennacheryb nałożył na króla judzkiego Ezechiasza ogromny haracz i kazał go dostarczyć do Niniwy. Zarówno Izrael jak i później Juda stały się ofiarami imperializmu asyryjskiego ${ }^{39}$. W świetle tych przesłanek wydaje się jasnym, dlaczego Jonasz nie godzi się na miłosierdzie Boga dla Niniwy. Nie czyni dlatego, że jest ksenofobem czy purystą religijnym, który chce ustrzec religię żydowską przed jakimikolwiek wpływami ze strony „obcych”. Prawda o Bogu, który kocha i okazuje miłosierdzie, przebacza także prześladowcom, największym wrogom była dla niego nie do przyjęcia. Jonasz jest człowiekiem „z krwi i kości”, który rozbudza w sobie raczej nienawiść do nieprzyjaciół i oczekuje od Boga interwencji, której skutkiem byłoby przykładne ukaranie nieprzyjaciół. Jonasz wcale nie pragnie nieocalenia pogan, ale nie chce ocalenia wrogów. Jest to o wołanie o sprawiedliwość Boga w historii. Reakcja Boga jest jednak całkowicie nie po myśli Jonasza. Brzmi ona jak policzek wymierzony Jonaszowi, dlatego wobec tak nieakceptowalnej odpowiedzi Boga, woli on raczej umrzeć niż żyć.

Dopowiedzeniem do tej wizji Boga jest przesłanie Nowego Testamentu ze słynną Jezusową antytezą z Kazania na Górze: „Słyszeliście, że powiedziano: Będziesz miłował swego bliźniego, a nieprzyjaciela swego będziesz nienawidził. A Ja wam powiadam: Miłujcie waszych nieprzyjaciół i módlcie się za tych, którzy was prześladują, abyście się stali synami Ojca waszego, który jest w niebie" (Mt 5,43-45). W uzasadnieniu tego nakazu rozbrzmiewa bardzo mocno przesłanie podobne do tego z księgi Jonasza: „ponieważ On sprawia, że słońce Jego wschodzi nad złymi i dobrymi, i On zsyła deszcz na sprawiedliwych i niesprawiedliwych” (Mt 5,45). „W żydowskiej Palestynie I wieku określenia «wasi nieprzyjaciele» i «ci, którzy was prześladują» przywodziły na myśl przede wszystkim rzymskich ciemiężycieli. Jezus wzywa swych uczniów, by kochali i modlili się właśnie za tych ludzi, którzy okupują ich kraj, nakładają na nich ciężkie podatki i stosują względem nich przemoc i niesprawiedliwość" ${ }^{40}$. Czy

39 Na temat rozwoju imperializmu asyryjskiego, którego ofiarami stały się najpierw Izrael, a potem także Juda zob. J. Warzecha, Historia dawnego Izraela, Warszawa 2005, s. 275-283; S.H. Horn, P.K. McCarter jr, Podzielona monarchia, w: Starożytny Izrael. Od Abrahama do zburzenia świątyni jerozolimskiej przez Rzymian, Warszawa 2007, s. 211-296.

40 C. Mitch, E. Sri, Ewangelia według św. Mateusza. Katolicki Komentarz do Pisma Świętego, Poznań 2019, s. 84-85. 
taka miłość jest możliwa? Po ludzku - co pokazuje historia Jonasza - jest nie do przyjęcia. Tylko Ten, który okazuje litość Niniwie „wielkiemu miastu, gdzie znajduje się więcej niż sto dwadzieścia tysięcy ludzi, którzy nie odróżniają swej prawej ręki od lewej, a nadto mnóstwo zwierząt" może człowieka do takiej miłości uzdolnić. Ma rację J.L. Sicre, który zauważa:

Być może zachowanie Jezusa w stosunku do Zacheusza, poborcy podatkowego, prototypu ciemiężcy $\mathrm{w}$ czasach NT, jest najlepszym sposobem, aby zrozumieć przesłanie tego dzieła. Opowiadanie Łukasza mówi o dobrowolnym zbliżeniu się Jezusa do wyzyskiwacza, które powoduje jego nawrócenie i zbawienie (Łk 19,110). Działanie Jezusa, aby „szukać i zbawić to, co zginęło” jest refleksją nad takim samym pragnieniem Boga, aby Niniwa się nawróciła ${ }^{41}$.

Podsumowując, głównym tematem Księgi Jonasza nie wydaje się ani uniwersalizm zbawczy, ani misyjne powołanie Izraela. Głównymi bohaterami tej księgi są Jonasz i Bóg, a cała narracja koncentruje się na konflikcie między tymi dwiema postaciami. Podstawą tego konfliktu jest Jonaszowe widzenie Boga. Jest to konflikt pomiędzy sprawiedliwością a miłosierdziem Boga. Jonasz stoi po stronie sprawiedliwości, Bóg po stronie miłosierdzia. Miłosierdzie Boga w odniesieniu do pogan jest akceptowalne dla Jonasza (ocalenie przez Boga pogańskich marynarzy ze sztormu, które prowadzi ich do nawrócenia do jedynego Boga). Tego, czego nie potrafi zaakceptować Jonasz to fakt okazania miłosierdzia przez Boga największemu wrogowi, prześladowcy Izraela, którego symbolem jest Niniwa. Narracja Księgi Jonasza zmierza do ostatniego pytania $(4,10)$, funkcjonującego w narracji jako „permanentna luka”, która jako taka nie uzyskuje bezpośredniej odpowiedzi. Do odpowiedzi na nie jest zaproszony Jonasz, są zaproszeni czytelnicy, którzy zamiast narratora powinni dopisać koniec tej historii własnym życiem, Jest to zaproszenie do 1) odkrycia prawdy o Bogu, który ukazuje miłosierdzie wszystkim ludziom, w tym także największym prześladowcom i wrogom oraz do 2) okazania miłosierdzia wrogom i prześladowcom. Cała księga przygotowuje nowotestamentowe objawienie Boga-Miłości, który sprawia, że „słońce Jego wschodzi nad złymi i dobrymi, i On zsyła deszcz na sprawiedliwych i niesprawiedliwych". Tylko miłując drugiego człowieka, także wroga, można stać się „synami Boga, który jest w niebie”.

41 J.L. Sicre, Profetismo in Israele, s. 380. 


\section{Bibliografia}

Briks P., Opowieść o dziwnym proroku (Księga Jonasza), w: Księgi historyczne Starego Testamentu. Dziejopisarstwo okresu judaistycznego, Wprowadzenie w Myśl i Wezwanie Ksiąg Biblijnych 3, cz. II, Warszawa 2007, s. 182-205.

Briks P., Ksiega Jonasza jako element dyskusji nad założeniami reformy państwa izraelskiego w okresie perskim, Scripta Biblica et Orientalia 1 (2009), s. 91-106.

Brzegowy T., Miłosierdzie Boże nie zna granic (Księga Jonasza), w: Wielki świat starotestamentalnych proroków. Od początków profetyzmu do Niewoli Babilońskiej, Wprowadzenie w Myśl i Wezwanie Ksiąg Biblijnych 4, Warszawa 2001, s. 129-152.

Brzegowy T., Prorocy Izraela, cz. II, Academica 19, Tarnów 2003.

Childs B.S., Il libro dell'Esodo. Commentario critico-teologico, Casale Monferrato 1995.

Clements R.E., The Purpose of the Book of Jonah, SVT 28, Leida 1975, s. 16-28.

Crouch W.B., To Question an End, to End a Question: Opening the Closure of the Book of Jonah, JSOT 62 (1994), s. 101-112.

Czerski J., Miłosierdzie w Ewangelii Św. Mateusza. Studium semantyczno-egzegetyczne, Opole 1986.

Freedman D.N., Lundbomm J.R., chānan, w: Theological Dictionary of the Old Testament, t. 5, Grand Rapids-Cambridge 1986, s. 22-36.

Fretheim T.E., The Message of Jonah, Minneapolis 1977;

Fretheim T.E., The Exaggerated God of Jonah, Word and World 27 (2007) n. 2, s. 125-134 .

Horn S.H., McCarter jr, P.K., Podzielona monarchia, w: Starożytny Izrael. Od Abrahama do zburzenia świątyni jerozolimskiej przez Rzymian, Warszawa 2007, s. 191-296.

Kotecki D., Co ma jeszcze chrześcijanin wspólnego z bożkami? Refleksja biblijno-teologiczna, w: Sentire cum Ecclesia, Fs. S. Grzechowiak, T. Makowski, red. P. Podeszwa, Gniezno 2004, s. 199-221.

Kotecki D., Bałwochwalstwo duchowe w Ewangelii według św. Marka na przykładzie uczonych w Piśmie w Mk 2,1-12, Teologia i Człowiek 3 (2004), s. 39-63.

Kotecki D., „On Bogiem wiernym, a nie zwodniczym” (Pwt 32,4). Refleksja biblijno-teologiczna nad wiernościa Boga w Starym Testamencie, CT LXXV (2005) n. 2, s. 13-38.

Malina A., Gli scribi nel Vangelo di Marco. Studio del loro ruolo nella sua narrazione e teologia, Katowice 2002.

Malina A., Znak Jonasza w tradycji i redakcji synoptycznej (Mt 12,38-42; 16,1-4; Łk 11,29-32), Biblica et Patristica Thoruniensia 2 (2009), s. 99-113. DOI: http:// dx.doi.org/10.12775/BPTh.2009.005

Mello A., Il Dio miserciordioso e gli attributi della sua misericordia (Es 34,6-7), PSV 29 (1994), s. 37-50.

Mitch C., Sri E., Ewangelia według św. Mateusza. Katolicki Komentarz do Pisma Świętego, Poznań 2019. 
Pikor W., „Luka” jako strategia narracyjna w Księdze Jonasza, Biblica et Patristica Thoruniensia 2 (2009), s. 13-36. DOI: http://dx.doi.org/10.12775/BPTh.2009.001

Point Ch., „Ojcze nasz, któryś jest w niebie...”, Communio 19 (1999) n. 2/110, s. 136-141 .

Powell M.A., Echoes of Jonah in the New Testament, Word and World 27 (2007), s. 157-164 .

Ratzinger J., Nadzieja, Communio 4 (1984) n. 4, s. 3-15.

Romaniuk K., Biblijny traktat o miłosierdziu, Ząbki 1994.

Schökel A.L., Sicre D.J.L., I Profeti, Roma 1996.

Schreiner J., Teologia Starego Testamentu, Warszawa 1999.

Sicre J.L., Profetismo in Israele. Il Profeta - I Profeti - Il messaggio, Roma 1995.

Sisti A., Misericordia, w: Nuovo Dizionario di Teologia Biblica, a cura di P. Rossano, G.Ravasi, A. Girlanda, Cinisello Balsamo 1988, s. 978-984.

Steffen U., Die Jona-Geschichte: Ihre Auslegung und Darstellung im Judentum, Christentum und Islam, Neukirchen-Vluyn 1994.

Struppe U., Die Bücher Obadja, Jona (NSK 24/1), Stuttgart 1996.

Tułodziecki T., Jonasz wobec pogan, Biblica et Patristica Thoruniensia 2 (2009), s. 37-48. DOI: http://dx.doi.org/10.12775/BPTh.2009.002

Tułodziecki T., Jonasz jako świadek diaspory asyryjskiej, Biblica et Patristica Thoruniensia 11 (2018) 2, s. 197-207. DOI: http://dx.doi.org/10.12775/BPTh.2018.010

Virgulin S., Peccato, w: Nuovo Dizionario di Teologia Biblica, a cura di P. Rossano, G.Ravasi, A. Girlanda, Cinisello Balsamo 1988, s. 1122-1140.

Wall R.W., Peter, Son of Jonah: the Conversion of Cornelius in the Context of Canon, JUNT 29 (1987), s. 79-90.

Warzecha J., Historia dawnego Izraela, Warszawa 2005.

Zawiszewski E., Księgi prorockie, Pelplin 1998. 